\title{
韓国産イチゴ新品種の特性と貯蔵性の品種間差異
}

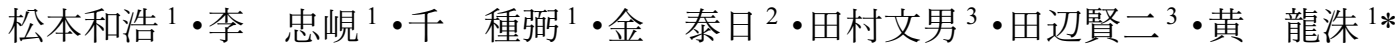 \\ ${ }^{1}$ 忠南大学校農業生命科学大学園芸学科 305-764 大田広域市 大韓民国 \\ 2 忠南農業技術院論山イチゴ試験場３20-862 忠清南道論山市大韓民国 \\ ${ }^{3}$ 鳥取大学農学部 $680-8553$ 鳥取市湖山町南
}

\section{Varietal Differences of Fruit Quality and Shelf Life in Strawberry Cultivars Developed in Korea}

\author{
Kazuhiro Matsumoto ${ }^{1}$, Chung-Hyun Lee ${ }^{1}$, Jong-Pil Chun ${ }^{1}$, Tae-Il Kim², \\ Fumio Tamura ${ }^{3}$, Kenji Tanabe ${ }^{3}$ and Yong-Soo Hwang ${ }^{1 *}$ \\ ${ }^{I}$ Department of Horticulture, College of Agriculture and Life Science, Chungnam National University, Daejeon 305-764, Korea \\ ${ }^{2}$ Nonsan Strawberry Experiment Station, Chungnam Agricultural Research and Extension Services, Chungnam 320-862, Korea \\ ${ }^{3}$ Faculty of Agriculture, Tottori University, Koyama, Tottori 680-8553
}

\begin{abstract}
Varietal differences of fruit firmness, soluble solids concentration, titratable acidity, anthocyanin concentration and soluble sugar composition as influenced by storage temperature were evaluated in 4 strawberry cultivars including 'Mae-hyang', 'Seolhyang', 'Keum-hyang' and 'Akihime'. The major soluble sugar in 'Keum-hyang' and 'Mae-hyang' was sucrose whereas 'Seolhyang' had a higher concentration of reducing sugars such as fructose and glucose as shown in the Japanese cultivar, 'Akihime'. Moreover, changes in sugar composition at each storage temperature differed according to the major soluble sugar. The levels of fruit firmness were increased by low temperature storage in all cultivars, and 'Mae-hyang' showed a remarkable increase. 'Mae-hyang' showed limited change in the acid concentration and sugar/acid ratio during both $4^{\circ} \mathrm{C}$ and $20^{\circ} \mathrm{C}$ storage. Furthermore, the decrease in the total soluble sugar in 'Mae-hyang' during $20^{\circ} \mathrm{C}$ storage was less than those in the other 3 cultivars. Thus, the shelf life of 'Mae-hyang' strawberry is longer than those of the other cultivars examined. However, the changes in acid concentration and sugar/acid ratio of 'Seol-hyang' at $20^{\circ} \mathrm{C}$ storage occurred earlier than those in the other cultivars. 'Keum-hyang' showed a high concentration of anthocyanin at both $4{ }^{\circ} \mathrm{C}$ and $20^{\circ} \mathrm{C}$ storage and the soluble sugar concentration decreased even at $4^{\circ} \mathrm{C}$ storage. These findings indicated that 'Mae-hyang' had a great potential for long term transport because a firm texture and stable quality were well maintained.
\end{abstract}

Key Words : ‘Akihime', firmness, 'Mae-hyang', skin color, taste

キーワード：‘章姫”，果肉硬度，果色，“メイヒャン’，食味

\section{緒言}

韓国も2 002 年に植物新品種保護国際同盟 (UPOV) に加 入し植物の品種保護を進めている。しかし，韓国で生産さ れるイチゴの多くが ‘レッドパール’，“章姫’といった日 本品種であり，ロイヤリティ一の支払いが大きな負担とな る。そのため, イチゴは未だに保護の対象植物に指定され ていない (Ministry of Agriculture and Forestry Republic of Korea, 2005). 一方, 日本の韓国産イチゴ輸入量は 2001 年 のピーク時には $1400 \mathrm{t}$ 余りあったものの, ロイヤリティー 問題の抜本的な対策を求める日本政府の強い姿勢もあり, 2006 年にはその $12 \%$ 程度にまで落ち込んでいる（財務省,

2007 年 6 月 5 日 受付. 2007 年 9 月 18 日 受理.

* Corresponding author. E-mail: yshwang@enu.ac.kr
2007）。こうした中, 韓国政府も先延ばしにしてきたイチゴ の保護作物への指定を 2008 年に行らべく, 国産新品種の育 成を強く推し進めてきた。その結果誕生し，普及が図られ ているのが ‘Mae-hyang (茵香)’ ’'Seol-hyang (雪香)' 抒 よび ‘Keum-hyang (錦香)’ の3 品種である (第 1 図)。こ れら 3 品種は忠清南道論山市にある忠南農業技術院論山イ チゴ試験場において ‘Mae-hyang’ は‘栃の峰” × ‘章姫”， 'Seol-hyang’ は章姫’ × ‘レッドパール’そして 'Keum-hyang' は ‘章姫” × ‘とち拈とめ’の交配によって育成されたもの である，近年，韓国でのイチゴ研究はこれらを中心に行わ れており，生産量も増加していることから，今後これらの 品種が韓国の主力品種になることが予想される (Ministry of Agriculture and Forestry Republic of Korea, 2005).しかし，こ れらの韓国産イチゴ品種の品質や貯蔵性については十分な 検討がなされていない. 


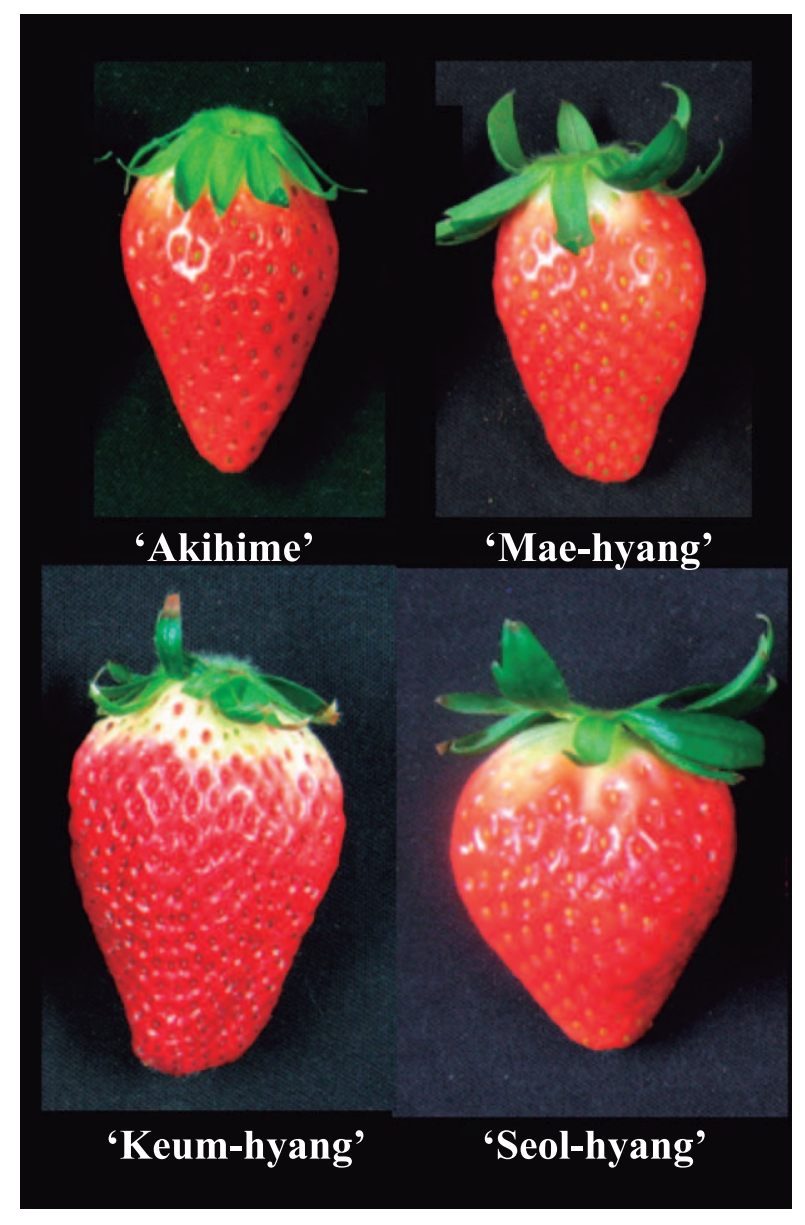

Fig. 1 Comparison of strawberry fruit appearance used in this experiment 'Mae-hyang', 'Keum-hyang' and 'Seol-hyang' are new strawberry cultivars developed in Korea.

イチゴの果実品質は食味, 外観, 貯蔵性, 輸送性など多 くの要因により評価される（荻原ら，1998）。特に, 糖組成 は消費者の嗜好に直接影響することから, 最も重要な要因 のひとつである。 また，イチゴ果実は輸送中や販売時に傷 害を受けやすく，棚持ちも悪いことから（門馬・上村， 1985), 果肉硬度を維持し, 貯蔵中の品質低下を防ぐ様々な 方策が栽培扔よび輸送の現場でも導入されている (Mitchell ら, 1996).

本研究では, 韓国産イチゴ品種の貯蔵性について基礎的 な情報を得ることを目的に, 糖組成と貯蔵中の品質変化を 調査した. その結果, 品種特性が大きく異なり, 貯蔵性に も差異があることが明らかになったので報告する.

\section{材料および方法}

\section{1. 植物材料}

実験には韓国産新品種 3 種 'Mae-hyang', 'Seol-hyang' 5 s よび ‘Keum-hyang’を‘章姫’を用いた（第 1 図）。2007年 2 月 20 日に韓国全羅北道益山市農協上り篤農家の同一圃場 で収穫された全 4 種の秀品イチゴを入手し, 直ちに忠南大 学校に持ち帰り実験を行った. 傷んだ果実を取り除いた後,
Table 1 Fresh weight and shape index of four strawberry cultivars used in the experiment.

\begin{tabular}{lcc}
\hline \hline Cultivars & $\begin{array}{c}\text { Fruit weight } \\
(\mathrm{g})\end{array}$ & $\begin{array}{c}\text { Shape index } \\
\text { (length/width } \times 100)\end{array}$ \\
\hline Akihime & $26.1 \pm 0.9^{\mathrm{z}}$ & $57.6 \pm 1.3$ \\
Seol-hyang & $29.3 \pm 1.1$ & $83.5 \pm 2.1$ \\
Mae-hyang & $26.7 \pm 0.4$ & $60.2 \pm 0.9$ \\
Keum-hyang & $33.8 \pm 0.9$ & $75.2 \pm 1.2$ \\
\hline
\end{tabular}

${ }^{\mathrm{z}}$ the average of 30 fruit \pm SE.

品種ごとに大きさや果色がほぼ等しい果実を選び，実験に 供試した．実験に用いた各品種の果実重および果形指数を 第 1 表に示した。緩衝材を敷いた発泡スチロール製の箱 $(36 \times 26 \times 11 \mathrm{~cm})$ に品種ごとに果実 15 果を入れ，ポリエ チレンフィルムで上面を覆った。 その後, $4^{\circ} \mathrm{C}$ また $20^{\circ} \mathrm{C}$ の恒温庫内に保蔵し, 2 日拈よび 4 日後に各々 1 箱を取り 出して果実品質を調查した。

果実は縦に 2 分割し, 一方を硬度, 可溶性固形物濃度打 よび酸度の測定に，他方をアントシアニン濃度おょび糖組 成の分析に供試した.

\section{2. 硬度, 可溶性固形物濃度および酸度の測定}

硬度は切断面を下向きに静置したとき，高さが最も高く なる部分の破断硬度を測定した。測定はレオメーター (COMPAC-100, サン科学, 東京) 飞直径 $5 \mathrm{~mm}$ の円柱プ ローブを装着し, 速度 $100 \mathrm{~mm} ・ \mathrm{~min}^{-1}$ で行った（ $\mathrm{n}=15 ）$. 硬度を測定した後, 果実 3 果をガーゼで包久搾汁し, 果汁 を採取した，得られた果汁を用い，可溶性固形物濃度を屈 折糖度計（PR-1，アタゴ，東京）で測定した。また，酸度 は果汁を希釈後 $0.1 \mathrm{~N} \mathrm{NaOH}$ で滴定し，クエン酸当量（\%) として求めた $(\mathrm{n}=5)$.

\section{3. アントシアニン濃度および糖組成の分析}

切断面を下向きに静置したとき, 高さが最も高くなる部 分から直径 $7 \mathrm{~mm}$ の果実片をコルクボーラーで打ち抜き, 表皮側の $0.4 \mathrm{~g}$ をントシアニン濃度の測定に用いた。 $1 \%$ の塩酸を含むメタノール溶液 $5 \mathrm{~mL}$ 中に 24 時間静置し, 抽 出した後, 10 倍に希釈した溶液の $530 \mathrm{~nm}$ に括ける吸光度 を分光光度計 (Optizen 2120 UV, Mecasys Co. Ltd., 大田, 韓国）で測定した（n=5）.

アントシアニンの測定に用いなかった部分の果肉は糖分 析に用いた. $5 \mathrm{~g}$ の果肉を $80 \%$ エタノール中で磨砕し, $100^{\circ} \mathrm{C}$ に 30 分間静置した後, 遠心分離し上清を採取した. 残椬を 再び $80 \%$ エタノール中で擋挥した後, 遠心分離し, 得られ た上清を前述の上清と合わせてガラス繊維ろ紙 $(\mathrm{GF} / \mathrm{C}$, Whatman, Middlesex, England）でろ過した。 ろ液はロータ リーエバポレーターを用いて濃縮し $10 \mathrm{~mL}$ に定容した。 こ の溶液を用いて糖組成を高速液体クロマトグラフ（CTS30, Younglin Instrument, 安養, 韓国）を用い, 移動相 : 75\% セトニトリル，カラム：Shodex Asahipak NH2P-50 4E（昭和 電工, 東京), RI 検出器 : RID 10A (島津製作所, 京都) で 分析した $(\mathrm{n}=3)$. 


\section{結果}

收穫時の韓国産新品種の果肉硬度を及ると, 'Seolhyang’ でやや低い值を示したものの，いずれも‘章姫”に 比べ高い值を示した (第 2 表)。いずれの品種も $4^{\circ} \mathrm{C}$ 貯蔵 区の果肉硬度が $20^{\circ} \mathrm{C}$ 貯蔵区に比べ高く, 特に收檴後 4 日 目に打いては有意な差異がみられた（第２表）。また“Maehyang' は貯蔵温度にかかわらず果肉硬度が他品種に比べて 高く，その傾向は $4^{\circ} \mathrm{C}$ 貯蔵区で顕著であった.

Table 2 Effect of storage temperature on fruit firmness of strawberry cultivars grown in Korea.

\begin{tabular}{|c|c|c|c|c|}
\hline \multirow{3}{*}{ Cultivar } & \multirow{3}{*}{$\begin{array}{c}\text { Storage } \\
\text { temperature } \\
\left({ }^{\circ} \mathrm{C}\right)\end{array}$} & \multicolumn{3}{|c|}{ Firmness (N) } \\
\hline & & \multicolumn{3}{|c|}{ Days after harvest } \\
\hline & & 0 & 2 & 4 \\
\hline \multirow[t]{2}{*}{ Akihime } & 4 & & $3.1 * * z$ & $2.8^{* *}$ \\
\hline & 20 & 2.4 & 2.1 & 2.1 \\
\hline \multirow[t]{2}{*}{ Seol-hyang } & 4 & & $3.2 \mathrm{NS}$ & $3.4^{*}$ \\
\hline & 20 & 2.7 & 3.0 & 2.9 \\
\hline \multirow[t]{2}{*}{ Mae-hyang } & 4 & & $3.6^{*}$ & $4.0^{* *}$ \\
\hline & 20 & 2.9 & 3.1 & 3.0 \\
\hline \multirow[t]{2}{*}{ Keum-hyang } & 4 & & $3.1 \mathrm{NS}$ & $3.5^{* *}$ \\
\hline & 20 & 2.9 & 2.8 & 2.7 \\
\hline \multicolumn{5}{|l|}{ ANOVA } \\
\hline \multicolumn{2}{|l|}{ Cultivar (A) } & *y & $* *$ & $* *$ \\
\hline \multicolumn{2}{|c|}{ Temperature (B) } & - & $* *$ & $* *$ \\
\hline \multicolumn{2}{|l|}{$\mathrm{A} \times \mathrm{B}$} & - & $*$ & NS \\
\hline
\end{tabular}

${ }^{\mathrm{z}} \mathrm{NS}, *, * *$ indicate non-significant and significant differences between storage temperatures at $P<0.05$ or 0.01 , respectively, by $\mathrm{t}$ test $(\mathrm{n}=15)$.

${ }^{\mathrm{y}} \mathrm{NS}, * * *$ indicate non-significant and significant differences at $P<0.05$ or 0.01 , respectively, by ANOVA $(\mathrm{n}=15)$.
収穫時の酸含量をみると, ‘章姫”が最も低い值を示し， 'Seol-hyang' もやや低い值を示した. 一方, 'Mae-hyang', 'Keum-hyang' はこれら 2 品種に比べ高い値を示した（第 3 表). いずれの品種も $20^{\circ} \mathrm{C}$ 貯蔵区の酸含量はわずかに増 加する傾向にあった．収穫後 4 日目の $20^{\circ} \mathrm{C}$ 貯蔵区の酸含 量は ‘Mae-hyang'を除き $4^{\circ} \mathrm{C}$ 貯蔵区に比べ有意に高い值 を示した (第 3 表)。また, 'Seol-hyang' では収穫後 2 日目 に $20^{\circ} \mathrm{C}$ 貯蔵区の酸含量が増加し, 糖酸比も $4^{\circ} \mathrm{C}$ 貯蔵区に 比べ有意に低下した.

本実験に用いた果実の収穫時の典型的な外観を第 1 図に 示した. 韓国産新品種 3 種は，いずれも ‘章姫”を親に持 つものの，その形質は様々であった。 'Mae-hyang' の外見は ‘章姫”に似たかなり長い円錐形を示し，大きさも同程度で あった. 一方, ‘Keum-hyang’ は横幅の広い長円形, ‘Seolhyang’ は円形を示し，“章姫”と比べると大型の果実であっ た（第 1 図，第 1 表).

収穫時のアントシアニン濃度をみると，'Keum-hyang’は 果肉にも着色がみられたため, 他品種に比べ著しく高い值 を示した（第 4 表）。いずれの品種も， $20^{\circ} \mathrm{C}$ に比べて $4{ }^{\circ} \mathrm{C}$ 貯蔵により果色の変化が抑制されたが, ‘Keum-hyang’は $4^{\circ} \mathrm{C}$ 貯蔵区に拈いても他品種に比べ高いアントシアニン濃 度を示し，収穫後 4 日目には他品種の $20^{\circ} \mathrm{C}$ 処理区と同等 の值を示した（第 4 表）.

収穫時の総可溶性糖含量は ‘章姫’ が他品種に比べ低い 值を示したものの韓国産 3 品種間では大きな差異はみられ なかった。 また，各品種の糖組成をみると，“章姫”执よび 'Seol-hyang' はフルクトースとグルコースの割合がスク ロースに比べて高く， 'Mae-hyang'および 'Keum-hyang' はスクロースの割合がフルクトース拈よびグルコースに比 ベて高かった（第 5 表).

Table 3 Effect of storage temperature on acid concentration and a sugar/acid ratio of strawberry cultivars grown in Korea.

\begin{tabular}{|c|c|c|c|c|c|c|c|}
\hline \multirow{3}{*}{ Cultivar } & \multirow{3}{*}{$\begin{array}{c}\text { Storage } \\
\text { temperature } \\
\left({ }^{\circ} \mathrm{C}\right)\end{array}$} & \multicolumn{3}{|c|}{ Acid content $(\%)$} & \multicolumn{3}{|c|}{ Sugar/acid ratio ${ }^{\mathrm{x}}$} \\
\hline & & \multicolumn{6}{|c|}{ Days after harvest } \\
\hline & & 0 & 2 & 4 & 0 & 2 & 4 \\
\hline \multirow[t]{2}{*}{ Akihime } & 4 & & $0.49 \mathrm{NS}^{\mathrm{z}}$ & $0.50 * *$ & & $17.5 \mathrm{NS}$ & $17.5^{*}$ \\
\hline & 20 & 0.48 & 0.50 & 0.59 & 15.7 & 17.8 & 15.7 \\
\hline \multirow[t]{2}{*}{ Seol-hyang } & 4 & & $0.54 * *$ & $0.52 * *$ & & $18.2^{* *}$ & $18.5^{* *}$ \\
\hline & 20 & 0.54 & 0.70 & 0.66 & 17.4 & 13.6 & 15.1 \\
\hline \multirow[t]{2}{*}{ Mae-hyang } & 4 & & $0.69 \mathrm{NS}$ & $0.68 \mathrm{NS}$ & & $15.4 \mathrm{NS}$ & $15.3 \mathrm{NS}$ \\
\hline & 20 & 0.66 & 0.68 & 0.77 & 15.1 & 15.0 & 14.5 \\
\hline \multirow[t]{2}{*}{ Keum-hyang } & 4 & & $0.70 \mathrm{NS}$ & $0.69^{* *}$ & & $14.0 \mathrm{NS}$ & $12.7 \mathrm{NS}$ \\
\hline & 20 & 0.66 & 0.73 & 0.78 & 14.3 & 12.4 & 12.3 \\
\hline \multicolumn{8}{|l|}{ ANOVA } \\
\hline Cultivar (A) & & $* * \mathrm{y}$ & $* *$ & $* *$ & $*$ & $* *$ & $* *$ \\
\hline Temperature (B) & & - & $* *$ & $* *$ & - & $* *$ & $* *$ \\
\hline $\mathrm{A} \times \mathrm{B}$ & & - & $* *$ & NS & - & $* *$ & NS \\
\hline
\end{tabular}

${ }^{\mathrm{z}} \mathrm{NS},{ }^{*},{ }^{* *}$ indicate non-significant and significant differences between storage temperatures at $P<0.05$ or 0.01 , respectively, by t test $(\mathrm{n}=5)$.

${ }^{\mathrm{y}} \mathrm{NS}, *, * *$ indicate non-significant and significant differences at $P<0.05$ or 0.01 , respectively, by ANOVA $(\mathrm{n}=5)$.

${ }^{\mathrm{x}}$ Sugar/acid ratio was calculated based on the data of soluble solid concentration (Brix ${ }^{\circ}$ ) and titratable acidity (\%). 
Table 4 Effect of storage temperature on anthocyanin concentration of strawberry cultivar grown in Korea.

\begin{tabular}{|c|c|c|c|c|}
\hline \multirow{3}{*}{ Cultiver } & \multirow{3}{*}{$\begin{array}{l}\text { Storage } \\
\text { temperature } \\
\left({ }^{\circ} \mathrm{C}\right)\end{array}$} & \multirow{2}{*}{\multicolumn{3}{|c|}{$\begin{array}{c}\text { Anthocyanin content (O.D. value) } \\
\text { Days after harvest }\end{array}$}} \\
\hline & & & & \\
\hline & & 0 & 2 & 4 \\
\hline \multirow[t]{2}{*}{ Akihime } & 4 & & $0.23 \mathrm{NS}^{\mathrm{z}}$ & $0.17 * *$ \\
\hline & 20 & 0.13 & 0.25 & 0.61 \\
\hline \multirow[t]{2}{*}{ Seol-hyang } & 4 & & $0.26 \mathrm{NS}$ & $0.25 * *$ \\
\hline & 20 & 0.12 & 0.35 & 0.48 \\
\hline \multirow[t]{2}{*}{ Mae-hyang } & 4 & & $0.21 * *$ & $0.15^{* *}$ \\
\hline & 20 & 0.11 & 0.36 & 0.59 \\
\hline \multirow[t]{2}{*}{ Keum-hyang } & 4 & & $0.73 \mathrm{NS}$ & $0.60 * *$ \\
\hline & 20 & 0.34 & 0.85 & 1.04 \\
\hline \multicolumn{5}{|l|}{ ANOVA } \\
\hline \multicolumn{2}{|l|}{ Cultivar (A) } & $* * \mathrm{y}$ & $* *$ & $* *$ \\
\hline \multicolumn{2}{|c|}{ Temperature (B) } & - & $* *$ & $* *$ \\
\hline \multicolumn{2}{|l|}{$\mathrm{A} \times \mathrm{B}$} & - & NS & NS \\
\hline
\end{tabular}

${ }^{\mathrm{z}} \mathrm{NS}$, ** indicate non-significant and significant differences between storage temperatures at $P<0.01$, respectively, by t test $(\mathrm{n}=5)$.

${ }^{\mathrm{y}} \mathrm{NS}, * *$ indicate non-significant and significant differences at $P<0.01$, respectively, by ANOVA $(\mathrm{n}=5)$.

$4^{\circ} \mathrm{C}$ 貯蔵区では ‘Keum-hyang’ を除く 3 品種で貯蔵にと もないスクロース含量が増加した。 'Keum-hyang' のスク ロース含量は貯蔵 2 日目には増加したが 4 日目には総可溶 性糖含量とともに著しく減少した。“章姫”および ‘Seolhyang' はスクロース含量の増加にともないフルクトースお よびグルコースの含量が低下した. 一方, 'Mae-hyang' お よび ‘Keum-hyang' は貯蔵中にフルクトース拉びグル コース含量の変化がみられなかった（第 5 表）.

$20^{\circ} \mathrm{C}$ 貯蔵区ではいずれの品種とも総可溶性糖含量が貯 蔵日数とともに低下したが, ‘Mae-hyang' の低下が他品種 に比べ少なかった。 ‘章姫”打よび ‘Seol-hyang’ は $4{ }^{\circ} \mathrm{C}$ 貯 蔵区と同様, 貯蔵日数とともにフルクトースおよびグル
コース含量が低下したが，低下の割合は $4^{\circ} \mathrm{C}$ 貯蔵区に比べ 大きかった。 一方, $4^{\circ} \mathrm{C}$ 貯蔵区でみられたスクロース含量 の上昇はみられなかった. 'Mae-hyang' および 'Keum-hyang' はスクロース含量の低下が著しかった（第 5 表）.

\section{考察}

‘章姫”では果肉硬度が低いことが収穫後の取り扱いを困 難にしていたが，韓国産新品種の果肉硬度はいずれも‘章 姫”に比べ高く, 室温でもその傾向が維持された (第 2 表). 一般的に低温貯蔵によりイチゴの果肉硬度は上昇するが, その程度は品種ごとに異なることが報告されている (Pelayo ら，2003; Watkins ら，1999）。韓国産新品種の果肉 硬度は $4^{\circ} \mathrm{C}$ 貯蔵により $21 \%$ ～38\% と “章姫” の $16 \%$ に比 べ大きく上昇したが，特に 'Mae-hyang' の上昇が著しい ことから, 長期貯蔵に耐えらる有望な品種であると認めら れた（第 2 表）。また， ‘Mae-hyang’ は貯蔵温度にかかわ らず酸含量打よび糖酸比の変化が小さく（第 3 表）， $20{ }^{\circ} \mathrm{C}$ 貯蔵区に拈ける総可溶性糖含量の低下子 $15 \%$ と他品種の 21 \%〜 23\%に比べ少ないなど（第 5 表），安定した貯蔵品質 を示した。一方, ‘Seol-hyang’ は $20^{\circ} \mathrm{C}$ 貯蔵区に拈いて収 穫後 2 日目に酸含量の急激な上昇がみられ，糖酸比も大き く低下したことから，品質の変化が起こりやすい品種であ ると認められた (第 3 表). 'Keum-hyang' は他の供試品種 と異なり4C 貯蔵区においてもアントシアニン濃度が高く (第 4 表)，果色も黒味を帯びていた。 また，貯蔵 4 日目に は， $4{ }^{\circ} \mathrm{C}$ 貯蔵区においても可溶性糖含量が急激に低下した (第 5 表).このように低温で貯蔵した場合でも果色の変化, 糖含量の低下といった成熟〜老化の過程を十分に遅延させ ることができなかったことから，'Keum-hyang’ は長期貯 蔵には適さない品種であると考えられた。

果実の糖組成をみると ‘Seol-hyang’ は‘章姫’ 同様つ ルクトース拈よびグルコース（還元糖）主体のさわやかな 甘味を, 一方, ‘Mae-hyang’ および ‘Keum-hyang’ はスク

Table 5 Effect of storage temperature on soluble sugar concentration $\left(\mu \mathrm{g} \cdot \mathrm{g}^{-1} \mathrm{FW}\right)$ of strawberry cultivars grown in Korea.

\begin{tabular}{|c|c|c|c|c|c|c|c|c|c|}
\hline \multirow{2}{*}{ Cultivars } & \multirow{2}{*}{$\mathrm{DAH}^{\mathrm{z}}$} & \multicolumn{4}{|c|}{$4^{\circ} \mathrm{C}$} & \multicolumn{4}{|c|}{$20^{\circ} \mathrm{C}$} \\
\hline & & Fructose & Glucose & Sucrose & Total & Fructose & Glucose & Sucrose & Total \\
\hline \multirow[t]{3}{*}{ Akihime } & 0 & $25.3 \mathrm{a}^{\mathrm{y}}$ & $22.9 \mathrm{a}$ & $16.1 \mathrm{~b}$ & $64.3 \mathrm{a}$ & $25.3 \mathrm{a}$ & $22.9 \mathrm{a}$ & $16.1 \mathrm{a}$ & $64.3 \mathrm{a}$ \\
\hline & 2 & $21.3 \mathrm{~b}$ & $17.9 \mathrm{~b}$ & $27.0 \mathrm{a}$ & $66.2 \mathrm{a}$ & $22.0 \mathrm{ab}$ & $16.9 \mathrm{~b}$ & $13.5 \mathrm{a}$ & $52.4 \mathrm{~b}$ \\
\hline & 4 & $22.4 \mathrm{~b}$ & $19.3 \mathrm{~b}$ & $27.3 \mathrm{a}$ & $69.0 \mathrm{a}$ & $19.5 \mathrm{~b}$ & $17.2 \mathrm{~b}$ & $14.7 \mathrm{a}$ & $51.4 \mathrm{~b}$ \\
\hline \multirow[t]{3}{*}{ Seol-hyang } & 0 & $28.9 \mathrm{a}$ & $26.2 \mathrm{a}$ & $21.9 \mathrm{~b}$ & $77.0 \mathrm{a}$ & $28.9 \mathrm{a}$ & $26.2 \mathrm{a}$ & $21.9 \mathrm{a}$ & $77.0 \mathrm{a}$ \\
\hline & 2 & $27.1 \mathrm{~b}$ & $24.0 \mathrm{~b}$ & $29.6 \mathrm{a}$ & $80.8 \mathrm{a}$ & $25.6 \mathrm{ab}$ & $19.7 \mathrm{~b}$ & $15.9 \mathrm{a}$ & $61.2 \mathrm{~b}$ \\
\hline & 4 & $26.7 \mathrm{~b}$ & $23.3 \mathrm{~b}$ & $28.6 \mathrm{a}$ & $78.6 \mathrm{a}$ & $22.7 \mathrm{~b}$ & $20.2 \mathrm{~b}$ & $16.6 \mathrm{a}$ & $59.5 \mathrm{~b}$ \\
\hline \multirow[t]{3}{*}{ Mae-hyang } & 0 & $16.5 \mathrm{a}$ & $14.0 \mathrm{a}$ & $42.7 \mathrm{~b}$ & $73.2 \mathrm{a}$ & $16.5 \mathrm{~b}$ & $14.0 \mathrm{ab}$ & $42.7 \mathrm{a}$ & $73.2 \mathrm{a}$ \\
\hline & 2 & $16.2 \mathrm{a}$ & $14.2 \mathrm{a}$ & $50.2 \mathrm{a}$ & $80.6 \mathrm{a}$ & $18.3 \mathrm{a}$ & $14.4 \mathrm{a}$ & $32.4 \mathrm{~b}$ & $65.1 \mathrm{~b}$ \\
\hline & 4 & $17.7 \mathrm{a}$ & $14.0 \mathrm{a}$ & $49.2 \mathrm{a}$ & $80.9 \mathrm{a}$ & $15.4 \mathrm{~b}$ & $13.4 \mathrm{~b}$ & $33.7 \mathrm{~b}$ & $62.5 \mathrm{~b}$ \\
\hline \multirow[t]{3}{*}{ Keum-hyang } & 0 & $20.0 \mathrm{a}$ & $17.6 \mathrm{a}$ & $34.8 \mathrm{~b}$ & $72.4 \mathrm{a}$ & $20.0 \mathrm{ab}$ & $17.6 \mathrm{a}$ & $34.8 \mathrm{a}$ & $72.4 \mathrm{a}$ \\
\hline & 2 & $19.9 \mathrm{a}$ & $16.4 \mathrm{a}$ & $42.5 \mathrm{a}$ & $78.8 \mathrm{a}$ & $22.3 \mathrm{a}$ & $18.1 \mathrm{a}$ & $23.4 \mathrm{~b}$ & $63.8 \mathrm{~b}$ \\
\hline & 4 & $17.5 \mathrm{a}$ & $15.1 \mathrm{a}$ & $27.4 \mathrm{~b}$ & $60.1 \mathrm{~b}$ & $19.0 \mathrm{~b}$ & $16.7 \mathrm{a}$ & $21.0 \mathrm{~b}$ & $56.7 \mathrm{~b}$ \\
\hline
\end{tabular}

${ }^{\mathrm{z}}$ days after harvest.

${ }^{y}$ Different letters within the same cultivar and column show a significant difference by Tukey-Kramer's HSD tests at the $5 \%$ level $(\mathrm{n}=3)$. 
ロース（非還元糖）主体の濃厚な甘味を示した（第 5 表）. さらに, 糖蓄積型ごとに各貯蔵温度における糖組成の変化 が異なることが明らかになった。つまり， $4^{\circ} \mathrm{C}$ 貯蔵区では

‘Keum-hyang’を除きいずれの品種もスクロース含量が増 加したが，還元糖主体の ‘Seol-hyang’および ‘章姫” で の久還元糖含量が有意に低下した. 一方, $20^{\circ} \mathrm{C}$ 貯蔵区にお ける全糖含量の低下の主な原因は還元糖主体の'Seolhyang’拈よび ‘章姫’ では還元糖含量の低下, 非還元糖主 体の ‘Mae-hyang’ および ‘Keum-hyang’ では非還元糖含 量の低下であった(第 5 表).トマトにおいて還元糖および 非還元糖蓄積型の違いはインベルターゼ活性の差異によっ て決定されることが示唆されている（大山，2000）。一方， イチゴにおいてはスクロース合成酵素およびスクロースリ ン酸合成酵素も糖組成に影響を与えていることが示唆され ている（濱野ら，2003; 荻原ら，2005）ことから，これら 3 種の酵素の働きが糖組成を決定する上で重要な役割を果た しているといえよう。しかしながら，貯蔵温度に対するこ れらの酵素の反応掞よび糖蓄積型の違いによる反応の差異 についての報告は見当たらない. 今後, CA や MA 処理の 条件などとあわせて酵素の反応特性を明らかにすること で，貯蔵拈よび輸送中にイチゴ果実の食味を適切に維持ま たは補正できる可能性も示唆された。

以上のように, 韓国産新品種イチゴ 3 品種の特性を“章 姫’ と比較した結果, ‘Mae-hyang’ が最も低温貯蔵中に硬 度と食味を保ちやすく, 室温貯蔵に打いても他品種に比べ 品質の変化が少ないことから, 長期貯蔵に耐えうる品種で あると考えられた。 また, 貯蔵温度はイチゴ果実の糖組成 に糖蓄積型ごとに異なる影響を与えることが明らかになっ た. 今後さらに輸送時の空気組成を精査することで品質維 持や食味の向上により効果的な輸送法が確立できるものと 考㝋られる。

\section{摘 要}

韓国産イチゴ品種 'Mae-hyang’，'Seol-hyang’ 扎よび ‘Keum-hyang’ と ‘章姫’を $4^{\circ} \mathrm{C}$ または $20^{\circ} \mathrm{C} て ゙ 4$ 日間貯蔵 し, 果肉硬度, 可溶性固形物濃度, 滴定酸度, アントシア ニン濃度および糖組成の品種間差異を調査した，各品種の 糖組成をみると 'Mae-hyang' 抢よび ‘Keum-hyang' はスク ロースが，'Seol-hyang’および ‘章姫’はフルクトースと グルコースが主体であった。 また糖蓄積型ごとに各貯蔵温 度に拈ける糖組成の変化が異なることが明らかになった。 低温貯蔵によりいずれの品種も果肉硬度が上昇したが, 特 に 'Mae-hyang' に拈いて顕著であった。 また, 'Mae-hyang' は貯蔵温度にかかわらず酸含量および糖酸比の変化が少な $<, 20^{\circ} \mathrm{C}$ 貯蔵区に扣ける総可溶性糖含量の低下も他品種比 ベ少なく, 安定した貯蔵品質を示した. 一方, 'Seol-hyang'
は他品種に比べ $20^{\circ} \mathrm{C}$ 貯蔵区において酸含量の上昇と糖酸比 の低下が起こりやすかった。 また，'Keum-hyang’はいずれ の貯蔵区でもアントシアニン濃度が高く, $4^{\circ} \mathrm{C}$ 貯蔵区でも 糖含量の低下がみられた。 これらの結果より, 'Mae-hyang' が他の韓国産新品種に比べ貯蔵中の硬度と品質を保ちやす い長期貯蔵に適した品種であると認められた。

\section{引用文献}

濱野 惠・山崎博子・本多一郎. 2003. イチゴ果実の生長 に伴う糖含量および糖代謝酵素活性の変化. 園学雑. 72 (別 2) : 162.

Ministry of Agriculture and Forestry Republic of Korea. 2005. Identification of strawberry cultivar through molecular marker, and development of cultural practices and postharvest management system for strawberry. MAF Korea Bul. (Korean with English abstract).

Mitchell, F. G., E. Mitcham, J. F. Thompson and N. Welch. 1996. Handling strawberries for fresh market. Publication 2442, University of California, Communication Services-Publications, Division of Agriculture and Natural Resources, Oakland, CA.

門馬信二・上村昭二.1985. イチゴ果実に括ける果皮扎よ び果肉の硬さの遺伝. 野菜試報. B5: 49-59.

荻原 勲・原田 慧・峠谷百合子・鈴木 栄・西窪伸之・ 片山義博. 2005. イチゴ果実の成熟過程における糖含 量とインベルターゼ，スクロースシンターゼ拈よびス クロースリン酸シンターゼ活性の変化. 園学雑. 74 (別 2) : 179 .

荻原 勲・宮本 亮・羽布津真典 - 鈴木雅人 ・ 箱田直紀 志村 勲. 1998. イチゴ果実内の糖含量・糖組成の品 種, 収穫年次, 成熟期および作型による相違. 園学雑. 67: 400-405.

大山暁男．2000．トマト（Lycopersicon esculentum Mill.）酸 性インベルターゼの生理的機能に関する研究. 野茶試 研報. 15: 17-62.

Pelayo, C., S. E. Ebeler and A. A. Kader. 2003. Postharvest life and flavor quality of three strawberry cultivars kept at $5{ }^{\circ} \mathrm{C}$ in air or air $+20 \mathrm{kPaCO}_{2}$. Postharv. Biol. Technol. 27: 171183.

Watkins, C. B., J. E. Manzano-Mendez, J. F. Nock, J. Zhang and K. E. Maloney. 1999. Cultivar variation in response of strawberry fruit to high carbon dioxide treatments. J. Sci. Food Agric. 79: 886-890.

財務省. 2007. 財務省貿易統計.〈http://www.customs.go.jp/ toukei/info/index.htm〉. 